\title{
Between the School and the Academy: The Struggle to Promote Teacher Research at Columbia University's Lincoln School, $1917-1935$
}

\section{Fonna Perrillo}

\begin{abstract}
This essay examines the development of a research faculty and culture at the Lincoln School, a laboratory school founded in 1917 by the Rockefeller General Education Board (GEB) at Teachers College, Columbia University. The school was dedicated to the production of education research by practicing teachers. The essay focuses in particular on the role played by the two men first charged by the GEB to organize and administrate the school, Abrabam Flexner and Otis Caldwell, and some of the school's teachers. Flexner and Caldwell promoted a working environment marked by experimentation, academic freedom, and faculty collaboration. This leadership model created tensions between Flexner and Caldwell and some Teachers College faculty over the use of Lincoln School classrooms as a resource for education research. Over the twenty-four years of the school's existence, Lincoln School teachers published bundreds of studies and textbooks focusing on curriculum development, child development, teaching techniques, and democratic school administration. In a profession where members are expected to be consumers rather than creators of knowledge, and practitioners rather than "experts," the teachers and administrators of the Lincoln School defied many of the most foundational premises that bave guided schools and the production of education research alike.
\end{abstract}

In 1936, teacher Alice Stewart described in Teachers College Record a new course of study that she and her colleagues designed for their ninth grade students at the Lincoln School, a laboratory school at Teachers

\footnotetext{
Jonna Perrillo is associate professor of English Education at the University of Texas at El Paso. The author thanks the anonymous reviewers of HEQ for their thoughtful critiques. The research for this article was supported by a grant from the Rockefeller Archive Center in Sleepy Hollow, New York.
} 
College, Columbia University, underwritten since its founding in 1917 by the Rockefeller General Education Board (GEB). Stewart's course, Living in a Machine Age, was an ambitious testament to the progressive philosophies central to the school's design. Over a span of months, students spent ten days living in a historic village studying agrarian tools, traveled around New York City to study electricity and the water supply, and disassembled a car motor in the school's yard. The curriculum called for the collaboration of teachers in home arts, science, social studies, and physical education. ${ }^{1}$ If its design sounded familiar to teachers at other elite progressive schools, however, Stewart's writing about it reflected a more unique mission for Lincoln: for teachers to produce education research that, in the words of the school's primary designer Abraham Flexner, would "influence education practice and serve as a seminary for the training of teachers" throughout the nation. ${ }^{2}$ To Flexner, Lincoln's central purpose was to improve curricula in all American schools, most of which lacked the elite faculty, students, and resources the Lincoln School possessed. Aware of these distinctions, he tasked teachers like Stewart with producing research that would expand readers' thinking rather than encourage its wholesale imitation. To enable this, he and the school's other leaders promoted a working environment marked by experimentation, academic freedom, and faculty collaboration that was as atypical in $\mathrm{K}-12$ education as was the scholarship the school's teachers created.

This essay examines the development of a research faculty and culture at the Lincoln School in the interwar period, especially in terms of the essential role played by the two men first charged by the GEB to organize and administrate the school, Abraham Flexner and Otis Caldwell, and some of the teachers whom they hired. Understanding the Lincoln School's workings is important not just for what it illuminates about the state of teacher professionalism in the interwar period, but for how we conceptualize the profession of teaching in our own time. As Dan Lortie argues in Scboolteacher, teachers are anomalous professionals in that they "can be considered outstanding ... without being thought to have made a single contribution to knowledge of teaching in general; the ablest people in the occupation are not expected to add to the shared knowledge of the group." The Lincoln School offered a different vision of the profession, one that permitted, in Flexner's terms, "highly qualified teachers a chance to make in their respective

\footnotetext{
'Alice Stewart, "Living in a Machine Age," Teachers College Record 39 (1936): 494 505 .

${ }^{2}$ Abraham Flexner, A Modern School (New York: The General Education Board, 1916), 10.

${ }^{3}$ Dan C. Lortie, Schoolteacher: A Sociological Study (Chicago: University of Chicago Press, 1975), 241.
} 
fields constructive contributions to educational materials." ${ }^{4}$ To accomplish this, teachers first had to straddle what John Dewey called being a "studen[ $[t]$ of subject-matter and studen $[t]$ of mind-activity" and what David Labaree has named the "conflicting professional views between teacher and researcher." Among these conflicts, Labaree identifies the tensions between the normative and the analytical, the experiential and the theoretical, and the particular and the universal. ${ }^{6}$ At the Lincoln School-where faculty performed as experts in the classroom and, at the same time, experimented with new and better ways of going about that work - teachers constantly negotiated these binaries. Rather than any particular method or model of research, however, the teachers' most valuable resource in traversing these differences were school leaders like Flexner and Caldwell, who identified as neither practitioner nor researcher and valued both professional outlooks in equal measure.

The GEB's insistence that the Lincoln School be founded as a laboratory school at Teachers College rather than as an independent school, as Flexner had wished, in many ways signaled Lincoln's greatest challenges and its conflicted relationship to the educational battles and research institutions of its time. The school came into being just one year after the 1916 founding of the American Educational Research Association (AERA), an organization that promoted the quantitative methodologies endorsed by administrative progressives and educational psychologists alike. ${ }^{7}$ The development of the AERA solidified the larger victory of these methodologies in a battle between the social and child-centered philosophies of John Dewey and the behaviorist, management-oriented ideas of Edward Thorndike. ${ }^{8}$ Thorndike and many of his followers, Ellen Lagemann has shown, believed that education should model itself on the "hard" sciences; as a result, he "scorned

${ }^{4}$ Memorandum to Dr. Caldwell, April 30, 1918, File 3607, box 349, series 1.2, General Education Board Archives (Rockefeller Archive Center, New York) (hereafter referred to as GEB).

5John Dewey, "The Relation of Theory to Practice in Education," in Teacber Education in America: A Documentary History, ed. Merle L. Borrowman (New York: Teachers College Press, 1965), 140-71, 151; and David F. Labaree, The Trouble with Ed Schools (New Haven, CT: Yale University Press, 2004), 86.

${ }^{6}$ Labaree, The Trouble witb Ed Schools, 83-108.

${ }^{7}$ Sherie Mershon and Steven Schlossman, "Education, Science, and the Politics of Knowledge: The American Educational Research Association, 1915-1940," American Fournal of Education 114, no. 3 (May 2008): 307-40.

${ }^{8}$ See Labaree, The Trouble with Ed Scbools; Ellen Condliffe Lagemann, An Elusive Science: The Troubling History of Education Research (Chicago, University of Chicago Press, 2000); Herbert M. Kliebard, Tbe Struggle for the American Curriculum, 1893-1958 (New York: Taylor \& Francis, 2004); Diane Ravitch, Left Back: A Century of Battles Over Scbool Reform (New York: Simon \& Schuster, 2001); and Lawrence A. Cremin, The Transformation of the School: Progressivism in Education, 1876-1957 (New York: Knopf, 1961). 
... school-based experimentation" at all of Teachers College's laboratory schools, including Lincoln. ${ }^{9}$ Lagemann captures these ideological battles and the Lincoln School's relationship to them, showing how beliefs about the science of education were debated through arguments over curricular studies in the 1920s and 1930s.

Yet how Lincoln School teachers and leaders persisted in developing practitioner-based research despite its low status and what that research represented to the field of education merits further analysis. The Deweyan-style progressivism that Lincoln teachers strove to embrace in their classrooms valued individual development, the influence of social experience, and experimentation, objectives that were impossible to capture by survey or exam. By necessity and design, Lincoln School teachers set out to produce a body of research that measured the value of curricular developments largely through teachers' and students' own work and observations. If their scholarship represented a bottomup approach to understanding teaching and learning, its production was neither grassroots nor ad hoc. Rather, examining the efforts of Lincoln School faculty and administrators reveals that practitioner research is as dependent on institutional investment and support as any other type of education research.

This support took the form both of school leaders and the GEB itself. To the GEB, the Lincoln School offered an opportunity both to make a mark in a developing science of education (a task the board went about in multiple, at times conflicting, ways) and to launch an elite education institution (one proven enough for the Rockefeller family to send four children). Founded in 1902, the GEB is often best known for its support of black education in the South, but in fact it dedicated 90 percent of its pre-1920 contributions to an array of other projects, including the creation of intelligence tests, the reform of medical education, and the increase of college faculty salaries. ${ }^{10}$ While the GEB would invest in multiple teacher-research projects in the 1930s (including the Eight-Year Study, which incorporated the Lincoln School), the early link between the school and research was grounded in Flexner's own vision. Flexner, a former headmaster of a progressive private school in Louisville, had proven his credentials for re-envisioning American

\footnotetext{
${ }^{9}$ Lagemann, An Elusive Science, 116.

${ }^{10}$ Statistic derived from Eric Anderson and Alfred A. Moss Jr., Dangerous Donations: Northern Pbilantbropy and Soutbern Black Education, 1902-1930 (Columbia, MO: University of Missouri Press, 1999), 220. For more on the historiography of the GEB and black education, see James D. Anderson, The Education of Blacks in the Soutb, 1860-1935 (Chapel Hill, NC: University of North Carolina Press, 1988); Mary S. Hoffschwelle, The Rosenwald Scbools of the American Soutb (Gainesville: University Press of Florida, 2006); William H. Watkins, The Wbite Architects of Black Education: Ideology and Power in America, 1865-1954 (New York: Teachers College Press, 2001).
} 
education through his 1910 report Medical Education in the United States and Canada, which prompted increased standards and rigor in American medical schools. In 1912, Flexner had been made a board member of the GEB, and in 1916, at its behest, he wrote what would become a celebrated work, $A$ Modern School, to outline how progressive ideals could best be embodied within a specific education institution. ${ }^{11}$ $\mathrm{He}$ understood American children to be living in an unprecedentedly technological and scientific society, where "railroads, wireless telegraphy, and international relations" made "abstract thinking ... never before ... so important a part of life." $12 \mathrm{He}$ believed outdated teaching methods and outdated curricula went hand in hand. "Nothing is commoner in the teaching of ancient languages and formal mathematics than drilling," he contended. ${ }^{13}$ The solution for Flexner was to modernize and reorganize the curriculum around four "fields"-science, industry, aesthetics, and civics-rather than artificial divisions along disciplinary lines. Traditional subjects that he saw lacking practical application in the modern world-Latin, Greek, and algebra-would be eliminated. Students would learn as much from field trips and participating in community-based learning projects as they did from textbooks. Flexner said little about modern teaching methods, but his claims that the school would serve as a "laboratory from which would issue scientific studies of all kinds of education problems" set forth a vision of teachers as practitioners, scientists, and change agents at once. ${ }^{14}$ At a time when independent progressive schools were flourishing across the nation, the expectation for an institution to foster and require teacher contribution was the most demanding and unique aspect of Flexner's vision. ${ }^{15}$

"For more complete accounts of Flexner's relationship with the GEB, see Raymond Fosdick, Adventure in Giving: The Story of the General Education Board, a Foundation Establisbed by Fobn D. Rockefeller (New York: Harper \& Row, 1962); Charles W. Eliot, "The Modern School," Education 38 (May 1918): 639-67; and Thomas Neville Bonner, Iconoclast: Abrabam Flexner and a Life in Learning (Baltimore: Johns Hopkins University Press, 2002).

${ }^{12}$ Flexner, $A$ Modern Sibool, 10.

${ }^{13}$ Flexner, $A$ Modern Scbool, 6.

${ }^{14}$ Flexner, A Modern Scbool, 23.

${ }^{15}$ This is especially true because of Dewey's 1904 departure from his Laboratory School, for which he once had held similar hopes. His replacement by Charles Judd, who believed that education research was the exclusive domain of academics, meant that any teacher research produced after Dewey left was a product of individual aspiration rather than school culture. For more on this shift, see Ellen Condliffe Lagemann, "The Plural Worlds of Education Research," History of Education Quarterly 29, no. 2 (Summer 1989): 183-214. For more on the school, see Katherine Camp Mayhew and Anna Camp Edwards, The Dewey Sibool: The Laboratory Scbool of the University of Cbicago, 1896-1903 (New York: Appleton-Century, 1936); Laurel N. Tanner, Dewey's Laboratory School: Lessons for Today (New York: Teachers College Press, 1997); and Anne Durst, Women 
The contributions of the Lincoln School were sizable. When Lawrence Cremin contended that "no single progressive school exerted greater or more lasting influence on the subsequent history of American education," he referred foremost to the research that was imagined, produced, and published out of the school. ${ }^{16}$ Experimentation was a key characteristic of 1920s education progressivism, but the productivity of the Lincoln School staff was difficult to match, and it played an important role in establishing the activity-based curriculum far beyond its own four walls. Teachers Harold Rugg and Hughes Mearns wrote works that fundamentally changed the instruction of social studies and English, respectively. The textbooks Rugg wrote during his work at the Lincoln School sold over four million copies, and Mearns' Creative Youth is widely credited with introducing the field of creative writing to $\mathrm{K}-12$ education. ${ }^{17}$ Many more teachers contributed less dramatic innovations. Lincoln School faculty published hundreds of studies and textbooks, focusing especially on curriculum development, child development, teaching techniques, and democratic school administration. Their articles were published in journals such as School and Society, Progressive Education, Science Education, The English fournal, Childhood Education, the Fournal of Education Research, and the Elementary Scbool fournal. The nation's largest education publishers, including Houghton Mifflin, Ginn and Company, the World Book Company, Rand McNally, Macmillan, and Scribner's, all published textbooks written by the Lincoln School staff. In addition, Lincoln School faculty offered in-service courses, demonstration workshops, and professionaldevelopment lectures for hundreds of schools and teacher associations across the nation. By the mid-1920s, more educators asked to visit and observe the school than it could accommodate. In 1926, 264 people from twenty-five states and five countries visited the Lincoln School in the month of April alone. ${ }^{18}$

Educators in the Progressive Era: The Women Bebind Dewey's Laboratory School (New York: Palgrave Macmillan, 2010).

${ }^{16}$ Cremin, The Transformation of the School, 280.

${ }^{17}$ As one sign of Rugg's influence, a 1931 national survey of social studies courses showed that the curriculum he advanced in his textbook series was required in 107 of the 301 schools surveyed. See Howard E. Wilson and Bessie P. Erb, "A Survey of Social-Studies Courses in 301 Junior High Schools," The School Review 39, no. 7 (September 1931): 497-507. For more on Rugg's influence, see Jonathan Zimmerman, Whose America? Culture Wars in the Public Scbools (Cambridge, MA: Harvard University Press, 2002), 64-80. For more on Mearns, see Joan Shelley Rubin, Songs of Ourselves: The Uses of Poetry in America (Cambridge, MA: Belknap, 2007) and Mark McGurl, The Program Era: Postwar Fiction and the Rise of Creative Writing (Cambridge, MA: Harvard University Press, 2009), 41, 89.

${ }^{18}$ Matthew H. Willing, "The Value of an Experimental School," School and Society 23 (May 1926): 614. 
The popular demand for the Lincoln School's findings and example might suggest that teacher-driven research was readily accepted, but in fact much of the significance of the Lincoln School was in its exceptionality. The teachers who made the school possible were an elite group in their qualifications, their accomplishments, and in the work they were invited to perform. They and their administrators were the best promoters of their contributions. To be certain, more scholarship on practitioner research appeared in the decades following the Lincoln School's foundation than before. When the Bureau of Education Research was founded in 1918, almost all of the projects it proposed and supported fell into the terrain of education psychology; a decade later, Bureau Director Walter Monroe concluded that education research included studies that were increasingly qualitative in method and that "several leaders have endeavored to stimulate classroom teachers to engage in experimentation and other types of educational research."19 But as a body of scholarship, the work in support of teacher research to which Monroe alluded failed to distinguish itself as a field, largely because its writers failed to reference each other (or publications by teachers) or to argue for a coherent method of training teachers to become researchers. ${ }^{20}$ Even Dewey, who argued that "the contributions that come from class-room teachers are a comparatively neglected field or ... an unworked mine," did relatively little to engage the work that existed. ${ }^{21}$ Practitioner research depended on a network of support and structures that academic researchers profited from but did little to provide for teachers. Instead, the creation of such networks was left to the faculty of the Lincoln School, its administrators, and the involved program officers of the GEB itself. Together, this group of investors argued for the potential of teacher research to widen the possibilities of educational knowledge, expand the purpose of education research, and realize the importance of what teachers might contribute.

\section{"The Foundation of All Education"}

From its inception, the Lincoln School attracted a stream of media attention and criticism. Conspicuously, Flexner's essay made no mention

${ }^{19}$ Walter S. Monroe, Charles W. Odell, Max D. Englehart, and Mabel R. Hull, Ten Years of Educational Research, 1918-1927, Bureau of Educational Research, College of Education (Urbana: University of Illinois, 1928), 48.

${ }^{20}$ For example, see B. R. Buckingham, Research for Teacbers (New York: Silver, Burdett, and Company, 1926); Orville G. Brim, "Research That Prevents Research," The Fournal of Educational Research 22, no. 3 (October 1930): 161-71; and Clifford Woody, "The Values of Educational Research to the Classroom Teacher," The Fournal of Educational Research 16, no. 3 (October 1927): 172-78.

${ }^{21}$ John Dewey, The Sources of a Science of Education (New York: Horace Liveright, 1929), 46. 
of the existing progressive schools that shared most of his overarching goals toward the curriculum and experimentation. Dewey, who had founded his laboratory school at the University of Chicago in 1896, took to the pages of the New Republic to challenge Flexner's characterization of experimental schools as entirely novel, chiding that the attention the school garnered had more to do with "the magic name of Rockefeller" than Flexner's ideas. "Fortunately for the promise of the new undertaking, the experimental school of the General Education Board is not a pioneer," Dewey argued. "The soil has been stirred, and seeds are quickening. Experimental work already done makes it possible to find teachers who are themselves capable of assuming the experimental attitude-the most difficult single condition to realize."22 If Dewey took umbrage at Flexner's assessment of the education landscape, he nevertheless agreed that in reforming schools, well-equipped teachers were the most valuable and difficult to secure resource.

Teachers College Dean James E. Russell, the most important link between the school and Columbia University, shared these concerns. In 1918, Russell wrote to Flexner to register his apprehensions. "It is exceptionally difficult to get teachers of the kind wanted in The Lincoln School, and it is always a problem to know how to hold onto the best," Russell explained. "The poorest eliminate themselves; the best are easily translated by selective offers elsewhere; those who remain are often just good enough to keep because they are not poor enough to dismiss." 23 Over time, Russell and Flexner differed over scores of issues related to the school, including the question of who should conduct the education experiments at the heart of the school's mission. Russell believed it should be Teachers College faculty, with teachers serving as research associates or support staff, workers who resided between the "extremes [of] 'practitioners' and 'experts," not clearly one or the other. ${ }^{24}$ Russell's view of the expert/practitioner divide, far from unique, was informed by what he characterized as the "constant friction between the professionally and academically minded" faculty in

\footnotetext{
${ }^{22}$ John Dewey, "Experiment in Education," The New Republic, February 3, 1917: 16. For more on the histories of elite progressive schools already in existence in 1916, see "Scbools of Tomorrow," Schools of Today: What Happened to Progressive Education, ed. Susan F. Semel and Alan R. Sadovnik (New York: Peter Lang, 1999); and Founding Mothers and Otbers: Women Educational Leaders During the Progressive Era, ed. Alan R. Sadovnik and Susan F. Semel (New York: Palgrave Macmillan, 2002).

${ }^{23}$ Dean James E. Russell to the General Education Board, May 1, 1918, File 3625, box 351 , series 1.2, GEB.

${ }^{24}$ James E. Russell to Abraham Flexner, September 28, 1921, File 3611, box 349, series 1.2, GEB. For more on the competition between Russell and Flexner, and particularly Flexner's concern that Russell wanted to use the school to advance Thorndike's research agenda, see Peter Lehman Buttenweiser, "The Lincoln School and Its Times, 1917-1948" (PhD Dissertation, Teachers College, Columbia University, 1968), 34-39, 43-44; and Lagemann, An Elusive Science, 113-17.
} 
his own college. While the academically minded professor "asks what the subject will do for the student," he explained, the professionally minded "asks what the student will do with the subject." ${ }^{25}$ As historians have traced, administrative progressives, who focused on testing and school governance, and pedagogical progressives, who focused on children's experiences and development, competed over almost every element of education, from who would lead in defining the mission of public schools to who would hold greater political sway in schools of education. ${ }^{26}$ But if these oppositions thrived in academic culture, they could not for Lincoln School teachers, who embraced the philosophical beliefs of the pedagogical progressives, while working under the practical pressures of preparing their students for the college entrance board examinations and the elite colleges into which they expected entry.

For this reason, it was all the more important for teacherresearchers like Alice Stewart to make clear that they were advocating for certain educational philosophies, practices, and experiences, not prescribing curricula to be adopted as is. Publications such as her article "Living in a Machine Age" described the scope of a particular unit while promoting the larger goals of activity- and student-focused learning to teachers across a wide array of institutional cultures and contexts. ${ }^{27}$ To accomplish this, Lincoln School teachers needed to serve as researchers of both their curricular decisions and their students, examining their written work, documenting classroom interactions, and imagining alternative possibilities. They also needed to understand at once theories of curriculum development, children's development, and progressive pedagogical techniques as they applied to their academic disciplines. Flexner and Caldwell, the school's first director, believed that the teachers who met these demands were experts, and, therefore, were best situated to conduct the kind of research that would successfully propel American schools-and the profession of teachinginto the future. Teachers should be central to developing, conducting and assessing their own experiments, Caldwell argued, "not merely

${ }^{25}$ James E. Russell, "A Summary of Some of the Difficulties Connected with the Making of a Teachers College" (1924) in Teacber Education in America: a Documentary History, ed. Merle L. Borrowman (New York: Teachers College Press, 1965), 210.

${ }^{26}$ For more on the differences between administrative and pedagogical progressives, see David F. Labaree, "Progressivism, Schools and Schools of Education: An American Romance." Pedagogica Historica 41, no. 1-2 (February 2005): 275-88; Lagemann, "The Plural Worlds of Educational Research"; David Tyack, The One Best System: A History of American Urban Education (Cambridge, MA: Harvard University Press, 1974); David Tyack and Elizabeth Hansot, Managers of Virtue: Public School Leadership in America, 1820-1980 (New York: Basic Books, 1982); and William J. Reese, America's Public Schools: From the Common School to 'No Child Left Bebind' (Baltimore, MD: Johns Hopkins University Press, 2011).

${ }^{27}$ Stewart, "Living in a Machine Age." 
carrying out experiments suggested by Thorndike and his students." 28 Yet despite their disagreements over the role of teachers in the production of education research, on this singular problem, Russell, Flexner, and Caldwell concurred: in order to revolutionize the profession and teacher preparation, the school needed teachers who already broke the mold.

The Lincoln School opened in 1917 with 116 students and twentyfive teachers, a faculty roster that consisted largely of a combination of former public school teachers, teachers hired away from other elite progressive schools, and junior-level college faculty. Yet this generous one-to-five teacher-to-student ratio obscures the challenges Flexner and Caldwell faced in the process of locating those teachers. Indeed, their reports of candidate interviews, which for Caldwell constituted an epic journey as he traveled the country to meet with teachers, reveal that they were nevertheless disappointed by many of those they encountered. Together, the two men sought teachers who were deeply knowledgeable about their subject matter and who held, in Caldwell's terms, "the right kind of view" toward experimentation and the problems with traditional teaching methods. These were difficult terms to satisfy, particularly for Flexner, who was more rigid, more risk adverse, and less confident that teachers could change or adapt in significant ways once trained in the wrong methods. He wanted teachers who had developed ideas about teaching out of academic and practical experience, but repeatedly he found candidates' scholarly training to be lacking. He rejected a prospective German teacher, for example, because she had learned the language from her father, had never traveled to Germany, and spoke with a pronunciation that was "distinctly Americanized." 9 In addition, he found teachers to lack a certain intellectual outlook and what he would repeatedly call a "cherished problem" that drove teachers to experiment. He responded viscerally to candidates who lacked "clear-cut ideas of what [they] would do" to identify research questions and whose "sole desire seemed to be to have the opportunity to work ... unhampered by routine and fixed method." 30 He disregarded the teaching philosophy of one teacher as "a childish document" because it failed to articulate any higher goal than engaging students. ${ }^{31}$

${ }^{28}$ Otis Caldwell to Abraham Flexner, December 9, 1916, File 3639, box 352, series $1.2, \mathrm{GEB}$.

${ }_{29}^{29}$ Abraham Flexner to Otis Caldwell, August 31, 1917, File 3605, box 348, series $1.2, \mathrm{GEB}$. GEB.

${ }^{30}$ Fred F. Bachman to Otis Caldwell, March 8, 1917, File 3603, box 348, series 1.2,

${ }^{31}$ Abraham Flexner to Otis Caldwell, August 24, 1917, File 3605, box 348, series 1 . 2 GEB. 
But if Flexner and Caldwell valued problems, most school administrators valued solutions. Teacher educators and administrators alike attempted to foster teachers' abilities to immediately address problems in the classroom or to problem solve, something that was antithetical to what the Lincoln School needed. ${ }^{32}$ This distinction undoubtedly presented the greatest challenge, for it indicated that teachers' absence of curiosity was rooted in a "lack of broad educational foundation and professional insight" to which few were ever introduced in their training or in mainstream schools. ${ }^{33}$ That is, Flexner's "cherished problems" were not born simply out of teachers' experiences in the classroom but out of their deep scholarly knowledge of their field and of teaching itself. One music teacher who exhibited little understanding of "the problems in school music ... had read none of Surette's books or papers ... nor could she tell me anybody else who is doing that sort of thing," Flexner lamented. As a result, he concluded, "I do not believe there is the slightest possibility that a person of this sort would do anything more than conscientiously teach music to her pupils." ${ }^{34}$ In other words, many of the teachers who failed to meet the standards of the Lincoln School did so in part because of the very same "conscientiousness" and quick certitude that was considered desirable in traditional schools.

Flexner and Caldwell's efforts in finding teachers well equipped to perform the work of the school's mission in its early years reflected the realities of teacher preparation. Studies of teacher-education programs abounded in the interwar period, and while they revealed diversity in the courses offered to students in different kinds of institutions, they also proved that teachers were unlikely to take coursework in research methods. A survey of twenty-eight major teacher training institutions in 1913 and 1914, for example, showed that while most students took courses in education history, teaching methods, and educational psychology, only two schools, the University of Iowa and the University of Washington, offered courses in education research. ${ }^{35}$ A survey of ninety-six teacher training institutions reflected that the terminology of "problems" had made its way into course titles (e.g., "Junior High

${ }^{32}$ For example, see George H. Betts, “Teachers' Remedies for Classroom Difficulties," The Elementary School fournal 29, no. 1 (September 1928): 54-62; John T. Greenan, "The Teacher's School Week," The School Review 30, no. 8 (October 1922): 592-98; Bertie Backus, "Solving the Problem of the Failure in English," The English fournal 9, no. 10 (December 1920): 579-83; and Thelma Hunt, "Measuring Teacher Aptitude," Educational Administration and Supervision 15 (May 1929): 334-42.

${ }^{33}$ Bachman to Caldwell, March 8, 1917, File 3603, box 348, series 1.2, GEB.

${ }^{34}$ Abraham Flexner to Otis Caldwell, August 22, 1917, File 3605, box 348, series 1.2 , GEB.

${ }^{35}$ Frederick E. Bolton, "Curricula in University Departments of Education," School and Society 2, no. 50 (December 1915): 832-34. 
School Problems," "Problems of Teaching High School," and "Problems of Teaching"), but such courses, offered at thirty-eight schools, were more likely to focus on classroom management than methods for locating and self-studying problems. ${ }^{36}$ The 1929 Commonwealth Teacher-Training Study, one of the most recognized studies on teacher education of the period, argued that teacher training programs had been organized unsystematically and without any regard to the traits most required for the job. Authors W. W. Charters and Douglas Waple surveyed teachers, administrators, parents, and students to rank eightythree traits required for teachers, including ambition, intellectual curiosity, scholarship, and leadership_all characteristics that might be of particular value to teacher-researchers. And yet while most of these traits were ranked with high value, so, too, were good taste, attractiveness, propriety, and thrift. ${ }^{37}$ On the job, then, teachers were expected to embody a wide array of qualities-some intellectual, some personality traits that made them likable to administrators, parents, and studentsthat went far beyond those with which academic researchers needed to contend. In training teachers, institutions faced similar competing demands, and much of the research about and by teacher educators reveals that they focused most on the interpersonal and organizational attributes considered essential for running a classroom. ${ }^{38}$

${ }^{36}$ Alfred Lawrence Hall-Quest, Professional Secondary Education in Teachers Colleges (New York: Teachers College, Columbia University, 1925), 36-47. See also Francis Edwin Peterson, Pbilosophies of Education Current in the Preparation of Teacbers in the United States: A Study of Four State Teacbers Colleges, Twelve Normal Scbook, and Nine Liberal Arts Colleges (New York: Teachers College, Columbia University, 1933); Geraldine Joncich Clifford and James W. Guthrie, Ed Scbool: A Brief for Professional Education (Chicago: University of Chicago Press, 1988); James Fraser, Preparing America's Teachers: $A$ History (New York: Teachers College Press, 2007); David F. Labaree, The Trouble with Ed Scbooks (New Haven, CT: Yale University Press, 2004); Lawrence A. Cremin, David A. Shannon, and Mary Evelyn Townsend, $A$ History of Teachers College, Columbia University (New York: Columbia University Press, 1954); and Jurgen Herbst, And Sadly Teacb: Teacher Education and Professionalization in American Culture (Madison: University of Wisconsin Press, 1989).

${ }^{37}$ W. W. Charters and Douglas Waples, The Commonwealth Teacher-Training Study (Chicago: University of Chicago Press, 1929), 51-76. I cite this study not to argue for the correlation between character traits and teacher preparation, but as one well-publicized view into expectations of teachers from the period. For more on teachers' traits, see John Almack, American Scbool Board Fournal 61 (November 1920): 29-31; I. N. Madsen, "The Prediction of Teaching Success," Educational Administration and Supervision 13 January 1927): 39-47; and Ned H. Dearborn, "A Program for the Selection of Prospective Teachers for Elementary Schools in New York State," Educational Administration and Supervision 14 (January 1928): 15-26.

${ }^{38}$ For example, see Betts, "Teachers' Remedies for Classroom Difficulties," 54 62; John T. Greenan, "The Teacher's School Week," The Scbool Review 30 (October 1922): 592-98; Bertie Backus, "Solving the Problem of the Failure in English," The English fournal 9 (December 1920): 579-83; and Thelma Hunt, "Measuring Teacher Aptitude," Educational Administration and Supervision 15 (May 1929): 334-42. 
By contrast, Caldwell and Flexner understood character to be essential to the intellectual work of conducting research. Together, they sought teachers with a "good personality, good scholarship, successful experience, [and] constructive ability ... to cooperate with others toward the realization of a clearly defined ideal." ${ }^{39}$ Flexner ruminated that in Caldwell's free reign to hire the best and most select group of teachers he could find, he faced the danger that "with a field of thoroughbreds, each may choose to run his own race." ${ }^{40}$ Regardless of the degree to which academic education research required collaboration, either in collecting data or simply in the ways in which scholars influenced the ideas of each other, many of its practitioners projected an image ofand claimed credit for-individualistic accomplishment that belied the greater truth. Even when academic researchers worked collaboratively, Caldwell worried, they had grown so insular that "specialists have lost perspective on the whole field ... [and] deep wells, while suggestive of depth and height of vision, are not suggestive of broad and comprehensive views." ${ }^{41}$ In this sense, then, Flexner and Caldwell resisted not just the individual qualities most often expected of teachers but institutional cultures that prioritized individualism and fragmentation.

The spirit of collaboration Flexner and Caldwell sought was essential to their own cooperative, intellectually challenging relationship. Flexner had pushed for the hiring of Caldwell, a biology professor at the University of Chicago he befriended when the two men surveyed the Gary schools for the GEB. Their partnership in founding the Lincoln School, especially in staffing it, was an important example to teachers. On the surface, their relationship often appeared uneven. Flexner, more combative than Caldwell and more established in the GEB, was demanding and unyielding as he sought to transform his vision into reality. To Flexner, American schools succeeded at making children happy but "attach[ed] infinitely too little value to scholarly and workmanly performance. ${ }^{n 2} \mathrm{He}$ saw the Lincoln School as a corrective and

\footnotetext{
${ }^{39}$ Memorandum for the Administrative Board of The Lincoln School, February 14, 1918, 6, File 3620, box 350, series 1.2, GEB.

${ }^{40}$ Abraham Flexner to the General Education Board, May 22, 1917, File 3606, box 349 , series 1.2 , GEB. It is difficult to know what to make of teacher collaboration in the Lincoln School, especially in the early period. While most reports, published and unpublished, suggest that teachers worked well together, Harold Rugg told a different story, and wrote, "I doubt there was a single member of the faculty in those early years who wasn't a rank individualist... . It was laissez faire in education, every man for himself... Eventually the school-like America-came to exemplify both ' $I$ ' and 'We,' but not in the earliest years!" See Harold Rugg, That Men May Understand: An American in the Long Armistice (New York: Doubleday, Doran and Company, 1941), 191.

${ }^{41}$ Otis W. Caldwell, "Some Social Obligations of Modern Science," 1923, 4, File 3620 , box 350 , series 1.2 , GEB.

${ }^{42}$ Abraham Flexner to Otis Caldwell, January 28, 1920, File 3610, box 349, series 1.2 , GEB.
} 
argued that "every teacher ought to try to be a productive contributor to some kind of literature ... [and] few of the teachers measure up to this standard now." 43 In contrast, Caldwell, who saw Flexner as "a source of courage" and "the real live wire in the educational world," at times felt insecure and fatigued by the demands of his position, one that he saw as "a great deal more work ... than [that] of furnish[ing] the money or material with which to work." +4 Yet Caldwell often better articulated how teacher research could benefit the profession and individual teachers. He believed fundamentally that research made teachers more active and involved thinkers, and could "transform routine teaching into creative teaching." ${ }^{45}$ By this he meant that research required teachers to trade the security and routine of teaching methods for a new approach; the experimental process asked faculty to inhabit the classroom as students and teachers at once.

In turn, Flexner tasked Caldwell to "get this point of view and attitude into them, eliminate such that cannot take it up, and select teachers who can." ${ }^{46}$ This responsibility to remedy the shortcomings of teacher education programs weighed on Caldwell as much as the running of the school itself, particularly in the schisms it caused with some faculty at Teachers College. He protected Flexner's vision in teacher hiring, even at the cost of cordial relationships with his academic colleagues. In the spring of 1917 , he wrote to Flexner that he was so "anxious to bring together a good group of honest, intelligent, industrious, high-idealed school people for this job" that he "found it necessary to decline to accept the judgment of a few educational advisors... . One or two of my friends here at Columbia have been a bit critical of me because I could not follow their advice," he confided. "As I see it, I must not lose sight of the goal which has been set." 47 That goal was one that teachers often misunderstood as well. Agnes de Lima, journalist and chronicler of the Lincoln School, described many teachers in progressive schools as "merely rebels against the traditional type of school," committed "to the quaint notion that all that was needed was a fondness for children

\footnotetext{
${ }^{43}$ Abraham Flexner to Otis Caldwell, March 8, 1918, File 3607, box 349, series 1.2, GEB.

${ }^{44}$ Otis Caldwell to Abraham Flexner, June 7, 1917, File 3604, box 348, series 1.2, GEB; and Otis Caldwell to Abraham Flexner, May 3, 1918, File 3607, box 349, series 1.2 , GEB.

${ }^{45}$ Otis Caldwell, "School Experimentation," Teachers College Record 33, no. 2 (November 1931), 127-51, 128.

${ }^{46}$ Flexner to Caldwell, March 8, 1918, File 3607, box 349, series 1.2, GEB.

${ }^{47}$ Otis W. Caldwell to Abraham Flexner, June 2, 1917, File 3604, box 348, series 1.2, GEB. For more on tensions between Flexner and the Teachers College, see John M. Heffron, "The Lincoln School of Teachers College: Elitism and Educational Democracy," in Semel and Sadovnik, "Schools of Tomorroww," Schools of Today, 141-70.
} 
and an amiable will to set them free." ${ }^{48}$ Such teachers viewed compassion as an antidote to scientific efficiency and standardization. Flexner and Caldwell, in fact, sought for teachers to become more scientific, but in a vastly different sense. The key, Caldwell argued, was in adapting the scientific method to teaching. "School experimentation does not mean merely trying something that is new or different," he explained in 1931. "To be worthy of trial with pupils who are in the process of being educated, a unit of experimental work should have the pre-thought of scholarly, trained, and experienced workers." 49 This process required teachers who "do not wait for emergent situations which call for inquiry, but help to develop the needed problems" just as a student, in the progressive education model, learns "when he is impelled by some sort of question to be answered." Whereas traditional education theories had little to say about teachers' development over time, Flexner and Caldwell envisioned that teachers would learn, not simply practice, over the course of their careers. "The elements of inquiry and research are at the foundation of all education," Caldwell contended, whether education referred to that of students or of teachers. ${ }^{50}$

But Caldwell was also under pressure to protect the mission of the school as a place of teacher experimentation, particularly when faced with Teachers College faculty and administrators who saw the school as a potential venue for their own research projects. "I must be able, in most cases, to select men of higher calibre than the graduate student who can afford to accept a short-term service on a particular task, nor can I rely merely on the short-term service of men who hold appointments elsewhere," he wrote sternly to Dean Russell in 1920. "The school can never be what its founders expect of it, if on one hand it is merely a 'way station' for promising young students, any more than it can if it becomes filled with older persons who are kept year after year in spite of possible non-productivity." 51 Despite finding more teachers who lacked the necessary qualifications than those who possessed them, Caldwell maintained his optimism and belief that a select few could serve the Lincoln School and the profession. This political and professional conviction that teachers, like scientific inquiry, were the foundation of education was the most significant promise the Lincoln School offered.

\footnotetext{
${ }^{48}$ Agnes De Lima, $A$ Scbool for the World of Tomorrow: The Story of Living and Learning in the Lincoln School (New York: Lincoln School of Teachers College, Columbia University, 1939), 41.

${ }^{49}$ Caldwell, "School Experimentation," 129.

${ }^{50}$ Caldwell, "School Experimentation," 127. 1.2, GEB.

${ }^{51}$ Otis Caldwell to Dean Russell, December 24, 1920, File 3610, box 349, series
} 


\section{The Freedom to Think}

While the productivity of the Lincoln School staff served as one testament to the quality of teachers the schools' directors located over time, the academic and pedagogical culture they helped to create within the school served as another. Writing to Flexner and Caldwell in 1921, Dean Russell urged the two to employ "enough teachers in the School whose main interest is in the children," for there existed "no greater danger than the conversion of the School into a mere experimental plant." 52 The unique nature of the Lincoln School required its faculty to balance service to the profession with service to their students. By all accounts, Russell's fear that the school could transform into a research mill did not materialize. Even with hundreds of studies published from the school, the majority of its faculty testified when surveyed that "students' interest and welfare should be paramount." ${ }^{53}$ Indeed, Lincoln School teachers consistently expressed that they were effective teachers precisely because the "opportunity to do creative work [was] as necessary to the teacher as the child." In contrast to schools where teachers performed "the same work year after year" and "ceas[ed] to grow," one former teacher wrote, Lincoln School teachers were positioned to continually "see the educative opportunities that lie all about her." 54 This belief in and appreciation of a particular notion of teacher qualityone that depended on the opportunity for consistent development and growth-was fundamental to the institutional culture of the school and upheld by teachers and administrators alike.

Personal and intellectual development was often at the root of teachers' curriculum design as well. For example, in his popular 1926 text Creative Youth, English teacher Hughes Mearns described his composition classes in this way: "It doesn't matter if sometimes we spend the time making iterated sketches of the same type of profile, or if the paper becomes a blotch of formless inky design. Sometimes we write the flattest stuff for half the time; then, without our even knowing it, the Silent Doors slide, and we are in the Never Never Land." ${ }^{55}$ Mearns's focus on self-expression more closely anticipated Louise Rosenblatt's ideas about reader autonomy and aesthetic experience in her $1935 \mathrm{Lit}$ erature as Exploration than it reflected the formalist approaches that

${ }^{52}$ James E. Russell to Abraham Flexner, September 23, 1921, File 3611, box 349, series 1.2, GEB.

${ }^{53}$ A Report on the Study of the Teachers College Schools, April 1939, 73, File 3618, box 350, series 1.2, GEB.

${ }^{54}$ Martha Peck Porter, The Teacher in the New School (Yonkers-on-Hudson, NY: World Book Company, 1931), 239.

${ }^{55}$ Hughes Mearns, Creative Youtb: How a School Environment Set Free the Creative Spirit (Garden City, NY: Doubleday, Page, 1926), 9. 
guided most literature instruction in the 1920s. For Mearns, a central moment in his own education came when meeting author Willa Cather, who asked him and his colleagues why they stressed literature's formal qualities over its effect on the reader. "The answer was, first ... the formal side of literature ... is the easier to teach," he confessed, "and second, we teachers do not seem to know anything else." 56 His experience with Cather taught Mearns something that few education theories at the time were equipped to do, liberating him, much as he hoped the experiences he created for his students would do for them.

The freedom of methods that Mearns and others embraced in their work was supported by a school culture that similarly embraced professional and academic freedom. Historically, private schools often provided little more financial reward for teachers than did many public schools; instead, one of the most compelling aspects of working at them was what teachers gained in terms of social mission and independence. ${ }^{57}$ Lincoln School teachers were required to share an ideology of experimentation, but Flexner and Caldwell-as well as the school's later directors-argued continually to protect teachers' independence in their work. For Harold Rugg, one of the school's most recognized teachers, the promise of independence compelled him to leave a junior position at the University of Chicago and teach at the Lincoln School for nine years, during which time he wrote his famous series, Man and His Changing Society. According to Rugg, his decision hinged on the fact that while he was "happy with [Charles] Judd and his men" he wasn't "really free" and needed instead "to study the total problem of America and education and make up my mind what should be done about it." At the Lincoln School, he later reminisced, "I became as free as probably no other person working on the controversial frontier in America has ever been free." 58 A team of fourteen teachers writing on the development of an elementary curriculum concurred: "Freedom to work as we wished! Buildings and supplies adequate, at least for the most part, for our work!" This freedom extended to the ability to study the classroom without the pressure for quick judgments that traditional schools required. Seeing their work as a series of "opportunities," the teachers remarked on their indebtedness to both the theorists who informed

\footnotetext{
${ }^{56}$ Mearns, Creative Youth, 10. Joan Shelley Rubin expands on and contextualizes Mearns's work on poetry instruction and the "new poetry" in Song of Ourselves, 108-39.

${ }^{57}$ On the history of private school teaching, see Peter J. Cookson Jr. and Caroline Hodges Persell, Preparing for Power: America's Elite Boarding Schools (New York: Basic Books, 1985), 86.

${ }^{58}$ Rugg, That Men May Understand, 187-88. For more on Rugg at the Lincoln School, see Elmer A. Winters, "Man and His Changing Society: The Textbooks of Harold Rugg," History of Education Quarterly 7, no. 4 (Winter 1967): 493-514.
} 
them and the "long period of research" with which they were provided to develop their ideas. ${ }^{59}$

Yet if some flourished under the freedom to think that the Lincoln School provided, the teacher attrition rates at the school indicate that others adjusted less well to the pressures that accompanied it. Despite the ways in which teaching at the Lincoln School seemed a golden opportunity for academically oriented, engaged teachers, directors faced considerable difficulty retaining them. In the school's first thirteen years, the teacher turnover rate averaged 18 percent. The Depression slowed turnover at the school as it did everywhere else, but in its first decade, attrition reached as high as 39 percent of the faculty in 1920 and 29 percent in 1927. In New York State, the teacher turnover rate in 1924 was 16 percent; at the Lincoln School it was 23 percent. $^{60}$ Across the school's first decade, nearly a third of the school's teachers left after only one year. ${ }^{61}$ At Horace Mann School, another Teachers College laboratory school less focused on education research, 22 percent of the faculty had taught at the school for thirteen or more years in 1930. At the Lincoln School, only one teacher had. ${ }^{62}$ Together, these figures suggest that a significant proportion of teachers found the school environment or the demands of the work unsuitable, perhaps even more so than in traditional schools. In this sense, Flexner and Caldwell's belief that not every capable teacher necessarily would be effective at or even enjoy research was proven true.

The school's designers were aware of the pressures teachers faced. GEB member Frank Bachman wrote upon visiting the school in 1917 that many of the teachers had "in some way gotten the impression that their status in the Lincoln School depends on doing some unusual and extraordinary thing." This pressure to do something extraordinary took a toll on teachers' work in the classroom, which inevitably threatened their ability to produce the kind of research expected of them. "A number of the teachers have lately had one, two, and three years in our best universities," Bachman reported, "with the result that their

${ }^{59}$ James S. Tippett and the Staff of the Elementary Division of the Lincoln School of Teachers College Columbia University, Curriculum Making in an Elementary School (Boston: Ginn and Company, 1927), 5, 43.

${ }^{60}$ All Lincoln School statistics taken from Survey Committee of the Affiliated Schools of Teachers College, Summary Report (Section 2), June 1930, 17 (Section 2), File 440B, box 62, series G, RG 2, Rockefeller Family Papers, Rockefeller Archive Center. For state statistics see National Education Association, Division of Research, "The Problem of Teacher Tenure," Research Bulletin of the National Education Association 2, no. 5 (November 1924): 139-75.

${ }^{61}$ Survey Committee of the Affiliated Schools of Teachers College, Summary Report (Section 2), 19.

${ }^{62}$ Survey Committee of the Affiliated Schools of Teachers College, Summary Report (Appendix), 15-16. 
heads are buzzing with theory, and for the time being are far away from a practical teaching attitude." ${ }^{33}$ The fear of teachers who were more like graduate students-intelligent but still subordinate to others' ideas rather than fully formed professionals in their own right-was a concern for all who worked on Lincoln School staffing. Caldwell found that teachers often possessed interesting ideas but were not yet versed enough in research methods to conduct experiments. To address the issue, he had to think more creatively and freely about faculty administration. Oftentimes, Lincoln School teachers taught different numbers of courses based on their role in experimentation. His first three years of directing the school showed him that while some "persons should give all their time to teaching, not being held individually responsible for any investigational work ... still others are capable of important investigations though not adapted to teaching." ${ }^{64}$ His willingness to treat teachers uniquely and to think creatively about school administration more closely resembled the thinking of an academic department chair than a school principal, and the faculty's productivity suggests it worked.

But the pull between research and teaching never achieved lasting equilibrium; Jesse Newlon, the school's third and final director, described the strain two decades after the school's founding. It was common for Lincoln School teachers to take graduate courses in research methodologies at Teachers College on top of their teaching positions. Because "teachers undertake more college course work than they are physically able to carry," Newlon described, "energy, interest, and enthusiasm are sometimes seriously sapped by work that centers largely outside of the school." Furthermore, he explained, teachers "occasionally ... becom[e] so engrossed in writing that [their] work in the schools is neglected. Professional writing, even the construction of textbooks, is of great value and should be fostered by the school. The difficulty lies in maintaining a balance of interests." 65 Even as many of the leading researchers at the Lincoln School taught fewer classes than others, in embracing the kind of work that was normally restricted to academics, Lincoln School teachers invariably put themselves at risk of experiencing the teaching/research tension that professors at developing research universities had come to know. Unsurprisingly, Newlon found that despite the philosophical support and academic freedom teachers were given, the demands of the work still got in the way. Indeed, he found

${ }^{63}$ Fred P. Bachman, Memorandum Re Observations at Lincoln School of Teachers College, November 23, 1917, 6, File 3606, box 349, series 1.2, GEB.

${ }^{6}$ Caldwell to Russell, December 24, 1920, File 3610, box 349, series 1.2, GEB.

${ }^{65}$ Survey Committee of the Affiliated Schools of Teachers College, Summary Report (Section 2), 131. 
that "a vast amount of valuable research and experimentation ha[d] been initiated, carried to a certain point, and then for lack of guidance and research facilities, allowed to lapse."

In addition to these kinds of pressures unique to teacherresearchers, however, was a more familiar one of power and reward. For Caldwell and Flexner, the school constituted a mission that was professional, political, and, ultimately, deeply personal, and teachers who worked at the Lincoln School, however much academic freedom they experienced, were expected to share in it. Unlike Caldwell, who gave up a university position to direct the school, Flexner had sacrificed nothing, which left him frequently insensitive to how much the school demanded of teachers. Caldwell reminded Flexner that he and the faculty came to the school because it offered a "larger opportunity for productive work for modern education and we were and are most anxious and serious in our efforts to be of service." ${ }^{17}$ But Flexner never forgot that the school's image rested on Caldwell and himself. The school's teachers, he wrote to Caldwell, "are not entitled to have any pride of opinion." From Flexner's point of view, "They ought to feel that they have been taken into an experimental enterprise, not because of their demonstrated value, but because it is hoped that they can enter into the spirit of the thing, consider objectively and without feeling suggestions and criticism, and help to make this thing a success by doing." ${ }^{\text {"F }}$ Flexner's conviction that teachers should feel fortunate rather than forthright colored his view of how to value their labor as well. Roughly one-third of the teachers who left the Lincoln School in its first decade did so because they were offered better positions elsewhere, many at universities where they could make use of their research skills and be paid more. ${ }^{69}$ One such person was mathematics teacher Raleigh Schorling, who taught at the school for its first six years and was one of its most prolific researchers. "The idea of the Lincoln School is an obsession," he wrote to Flexner. "It is not likely that I shall ever be so happy in my work again. But I can see no solution to the living problem in New York City."70

The issue of compensation was particularly vexed because teachers' salaries were limited by Flexner's stubborn belief that "The teacher's

\footnotetext{
${ }^{66}$ Survey Committee of the Affiliated Schools of Teachers College, Summary Report (Section 2), 70.

${ }^{87}$ Caldwell to Flexner, May 3, 1918, File 3607, box 349, series 1.2, GEB.

${ }^{68}$ Abraham Flexner to Otis Caldwell, December 3, 1917 , File 3606, box 349, series 1.2, GEB.

${ }^{69}$ Survey Committee of the Affiliated Schools of Teachers College, Summary Report (Section 2), 18.

${ }^{30}$ Raleigh Schorling to Abraham Flexner, January 11, 1923, File 3613, box 349, series 1.2, GEB.
} 
remuneration is her salary plus her scientific and educational opportunities."71 Teachers in public schools had long been expected to accept low salaries because their work constituted a public service; Flexner's belief that teachers should accept satisfaction from science was no better. But the school's finances were also limited because of his vision for the school itself. Teachers "need help," Russell wrote to the GEB in 1925 in an unsuccessful effort to secure permanent funding. But "the public ... does not care. If help comes, therefore, it must come from private sources, and public recognition can be expected only from a generation trained under better auspices." 72 To Russell, who worried about the potential financial drain the school could present to Teachers College, a citizenry educated within traditional schools could not be trusted to support experimentation or change. But neither did Flexner support the growth of the school to become more financially self-sustainable from tuition. When, early on, Caldwell suggested expanding the school's size, Flexner vigorously rejected the suggestion, arguing "The bigger the school, the greater the administrative routine and the larger the number of mediocre teachers that will inevitably be employed." Flexner feared a "great commodious plant" with "a big staff ... of which is mostly of the usual character," making "experimental and productive work ... merely incidental." ${ }^{73}$ For Flexner, more than for Caldwell, the importance of teacher research was always about transforming education more than transforming the profession, valuing the ends more than the means. Because of this, Lincoln School teachers' desire to have their work better compensated was repeatedly stymied by an argument that intellectual freedom and opportunity were reward enough. In this sense, the school was at its most conventional, for it asked teachers to contribute, but to contribute much for free.

And yet while these structural issues were real for Lincoln School faculty, the school's problem with turnover might be understood as a sign of success as well as a shortcoming. Many of the faculty who left the Lincoln School did so not for other private schools but for positions in teacher preparation. Math teacher Raleigh Schorling left the school for a position at the University of Michigan. Mearns went on to teach at New York University, and Rugg joined the faculty of Teachers College. Alice Stewart taught at the school for over ten years before leaving for Montclair State Teachers College. By 1938, former

\footnotetext{
${ }^{71}$ Abraham Flexner to Otis Caldwell, May 8, 1920, File 3610, box 349, series 1.2, GEB.

${ }^{72}$ James E. Russell to the General Education Board, April 30, 1925, File 3617, box 350 , series 1.2, GEB. GEB.

${ }^{73}$ Memorandum to Otis Caldwell, April 30, 1918, File 3607, box 349, series 1.2,
} 
Lincoln School teachers worked in teacher training institutions in at least ten states. ${ }^{74}$ Even Caldwell, who came to the Lincoln School a biology professor, went on to chair the Department of Education at Atlanta University. Taken together, these individual cases create a fuller picture of teachers who may have arrived at the Lincoln School with relatively little experience as researchers, but who left committed to the avocation of teacher education. As capacious as the Lincoln School was in its goals and ideas, teachers, once hooked on the project of teacher development, may simply have found universities more suitable places to work, as they could dedicate themselves entirely to the process. In so doing, they introduced the philosophies of the Lincoln School to new institutions, forging bridges between different kinds of contributions and contributors.

\section{Measuring Contribution}

By 1940, diminishing student enrollments throughout the Depression, waning interest on the GEB's endowment, and reduced research production as a result of the school's financial difficulties called for the college's trustees to revisit the school's future. Against Flexner's wishes and the protests of many Lincoln School parents and teachers, the trustees called for the school to merge with another Teachers College laboratory school, the Horace Mann School, in $1941 .^{75}$ In contrast to the Lincoln School, Horace Mann was an established demonstration school, an institution dedicated to performing best practices rather than experimenting with them. As the trustees described it, the Lincoln School was a victim of its own success. It had publicized its findings so effectively that "even in the schools which have resisted 'progressive education' as such, there has been a noticeable seepage of the methods." Because "the experimental application in the Lincoln School ... met

${ }^{74}$ Lincoln School teachers transferred to higher education institutions as diverse as Stanford, Wisconsin, Ohio State, California-Berkeley, Montclair State Teachers College, and Maryland State Teachers College. It is worth noting that while the low pay of the Lincoln School teachers was a product of the same gender dynamics that drove low pay in public K-12 schools, it was probably in line with other private progressive schools. The insufficient pay extended to all of the school's teachers. That said, male teachers appear to have been offered high-status university positions (i.e., at research universities rather than teachers colleges) in greater numbers than women. See Lincoln Scbool Comes of Age, 1917-1938 (New York: Lincoln School of Teachers College, Columbia University, 1938), 28-30.

${ }^{75}$ The merger between the two schools lasted for five years until the Horace MannLincoln School was closed and Teachers College transferred the GEB endowment to its general research fund. The demise of the Lincoln School and the role of its troubled political relationship with Teachers College in the merger, merits its own evaluation. Currently, the best treatment of this can be found in Buttenweiser, "The Lincoln School and Its Times, 1917-1948," 169-234. 
with a success that inspired widespread imitation, the movement can now be trusted to continue of its own momentum," they concluded. ${ }^{76}$ To Teachers College trustees and the GEB, the goals of the Lincoln School were finite and assessable: to create and promote a particular curriculum. But that exhibited a flawed understanding of the nature of teacher contribution, what the school had accomplished, and what it stood to accomplish still. In a profession where members were expected to be consumers rather than creators of knowledge, and practitioners rather than "experts," the teachers and administrators of the Lincoln School defied-and continue to defy-many of the most foundational premises that have guided schools and the production of education research alike.

As with the interwar period, our own time marks an important period in reconceiving how individual teachers contribute to and take ownership of the wider profession. What Walter Monroe referred to in the 1920s as the "worship of objective methods" could aptly describe the relationship between contemporary education policy and education research or "data." 77 In this context, teacher contribution takes on a heightened sense of importance: it serves to counter policies that have deprofessionalized teachers and to make visible the kinds of knowledge and understandings that modern scientific measurements are incapable of capturing. As in the 1920s and 1930s, teacher research often thrives independently of the forms of research inherited from the administrative progressives, but its presence at the AERA (where it is represented through two different special interest groups), and its cultivation and promotion by associations such as Project Zero and the National Writing Project, offer it a more expansive and professionalized context than teachers of the Lincoln School possessed.

It is of little surprise then that, over the last two decades, scholars have revived the question of what teachers can offer to education research and why it is important for them to contribute. ${ }^{78}$ In contrast to

\footnotetext{
${ }^{76}$ Report of the Special Committee of the Board of Trustees of Teachers College on Horace Mann-Lincoln School (June 1946), 29, File 3607, box 349, series 1.2, GEB. For a more complete account of the GEB's desire for the school to become more financially independent-the end goal of all of its sponsored projects-as well as the GEB's assessment of the Lincoln School's diminished influence in the light of broad school reforms, see Fosdick, Adventure in Giving, 222-25.

${ }^{77}$ Monroe, Ten Years of Educational Research, 48.

${ }^{78}$ For examples of this contemporary conversation see Marilyn Cochran-Smith and Susan L. Lytle, Inside/Outside: Teacber Research and Knowledge (New York: Teachers College Press, 1993); Cynthia Ballenger, ed., Regarding Children's Words: Teacber Research on Language and Literacy (New York: Teachers College Press, 2004); Gail Burnaford, Joseph Fisher, and David Hobson, eds., Teachers Doing Researcb: The Power of Action Tbrough Inquiry (Mahwah, NJ: Erlbaum Associates, 2001); Dixie Goswami and Peter R. Stillman, eds., Teacher Research as an Agency for Change (Montclair, NJ: Boynton/Cook, 1987);
} 
the interwar period, academic literature on teacher research is highly visible, more codified as a body of literature, and more engaged with actual teacher-produced research. On the whole, scholars and teachers alike have argued that a culture of teacher contribution must also be one of collaboration. To challenge the fact that practitioners' knowledge historically has been "subjugated knowledge" to that of academics, Susan Lytle and Marilyn Cochran-Smith contend, we must first recognize that teachers possess "the collective intellectual capacity to help pose the new adaptive challenges of practice and also create the knowledge and tools to address those problems by working together in inquiry communities."79 Lytle and Cochran-Smith note that classroom work is inherently local and localized; how to connect teachers' observations and understandings to other stakeholders is both an ideological challenge, as Labaree argues, and a political one. For teachers to transform their research into more widely applicable theories, they must depend on the kinds of networks with other practitioners, universities, and local communities that the Lincoln School provided to its staff. The story of Lincoln School faculty and leaders offers a model of how teachers can be helped in developing these networks as well as an example of the obstacles, including resistance from potential partners that must be overcome for practitioner research to flourish.

Historians and teacher educators have access to ways of understanding how teachers collaboratively resisted professional limitations imposed on them. The history of unionization, for example, offers a view into how teachers understood and responded to many of the structural challenges that accompanied their work. ${ }^{80}$ In contrast, a less well-known history of practitioner research, in which the Lincoln School plays just one role, offers a view into how teachers understood their work intellectually. Lortie argues that developing this history is

\footnotetext{
Ellen Meyers and Frances Rust, eds., Taking Action with Teacher Research (Portsmouth, NH: Heinemann, 2003); and Ann Lieberman and Lynne Miller, Teachers Caught in the Action: Professional Development That Matters (New York: Teachers College Press, 2001). The National Writing Project and its multitudinous publications also have made a compelling argument that teacher research promises professional, political, and intellectual agency for teachers.

${ }_{79}$ Marilyn Cochran-Smith and Susan L. Lytle, Inquiry as Stance: Practitioner Research in the Next Generation (New York: Teachers College Press, 2009), 159.

${ }^{80}$ See Marjorie Murphy, Blackboard Unions: The AFT and the NEA, 1900-1980 (Ithaca, NY: Cornell University Press, 1992); Kate Rousmaniere, Citizen Teacher: The Life and Leadersbip of Margaret Haley (Albany, NY: State University Press of New York, 2005); Wayne J. Urban, Why Teacbers Organized (Detroit, MI: Wayne State University Press, 1982); Jonna Perrillo, Uncivil Rights: Teacbers, Unions, and Race in the Battle for School Equity (Chicago: University of Chicago Press, 2012); Dorothy Shipps, Scbool Reform, Corporate Style: Cbicago, 1880-2000 (Lawrence, KS: University of Kansas Press, 2006); and Clarence Taylor, Reds at the Blackboard: Communism, Civil Rights, and the New York City Teachers Unions (New York: Columbia University Press, 2013).
} 
important because it can help teachers to "believe themselves capable of such work" and "surmount decades of subordination," a fact that remains true forty years after the publication of his book. ${ }^{81}$ For this reason, the history of the Lincoln School teachers is all the more important to recover. If the particular conditions under which Lincoln School teachers worked remain uncommon, there still lies an important lesson in the big themes their story casts, including how teachers challenged traditional and prevalent notions of expertise, the rewards they experienced in charting their work, and their need for willing partners and supporters in order to have the capacity to contribute.

${ }^{81}$ Lortie, Schoolteacher, 241. 